\title{
The impact of WOM on the acceptance of mobile banking
}

\author{
Giorgi ZARNADZE \\ Tomas Bata University, Zlin, Czech Republic \\ zarnadze@utb.cz \\ Inês Veiga PEREIRA \\ Polytechnic of Porto, Porto, Portugal \\ inespereira.iscap@gmail.com
}

\begin{abstract}
Purpose: This study is focused on researching the impact of WOM on the acceptance of mobile banking. This research offers insights into factors that affect the implementation of mobile banking applications.

Methodology: The research's inclusion was based on relevancy, authenticity, and reliability of information extracted from publication journals, and exclusion was based on non-relevancy and lack of authentic research. For the analyzes, consumer data were collected through a survey, and structural equations modelling, and path analysis were employed to test the research model.

Findings: The findings showed that WOM was the critical factor influencing consumer perceptions towards mobile banking. WOM also positively affects other factors impacting mobile banking acceptance, such as Ease of use, Perceived usefulness, Social Norms, Trust, Attitude, and intention.

Limitations: The most significant limitation of this study is that it only concentrates on internet users. Non-users are not considered.

Value: Many researchers studied the number of effects on mobile banking, but this work's uniqueness is that this paper focuses on WOM impact on mobile banking adoption. Its impact factor is considered the main contribution of this research.
\end{abstract}

Keywords: WOM, Mobile Banking, TAM, developing countries.

\section{Introduction}

The effect of digitalization is widespread in our lives, and it is impossible to visualize a life without it. Developments worldwide in different fields have made our lives very relaxed and effortless (Dass \& Pal, 2011). The appearance of mobile banking ( $\mathrm{m}$-banking) has turned on a new revolution in the banking industry because of its impact on the economy and society (Nguyen et al., 2020). Modern purchasing and sale modes have gone a reversal under the influence of technology. Mobile technology is commonly used in many business operations, and banking and financial services are not resistant to this (Al-Adwan \& Sammour, 2020). The rapid growth and acceptance of internet sales have stimulated banks and financial institutions to encourage their customers to use online and mobile banking methods to make payments and other associated banking transactions (Matute et al., 2016). Also, the escalation of mobile banking can be attributed to the multiplicity of difficulties encountered by consumers in accessing financial services with the aid of traditional modes of distribution (Kumar et al., 2020). Banks have been used by customers for a long time now, both for transactions and saving. Nowadays, m-banking has made all of these services more comfortable. Only with one app customers can transact online through their smartphone screens. Each bank usually has this M-Banking facility (Purwanto et al., 2020).

Over the last few decades, competition in the retail banking industry has grown increasingly intense. To increase competitiveness through improved customer convenience, many banks and 
financial institutions are actively developing new electronic banking products. These products provide customers with 24-h service regardless of location and provide banks with significant cost savings, increased transaction efficiency, and greater productivity. Simultaneously, the market for mobile and wireless services has emerged as one of the world's fastest-growing industries (Ho et al., 2020).

According to all the above, mobile banking seems to have a massive increase in future users (Yu et al., 2015). Latest investigations in this field showed that in developing countries, the expected numbers do not meet reality; there were some expectations that developing countries' user numbers would be higher than they are now (Purwanto et al., 2020). This supports the idea that just technological advancement does not automatically lead to high numbers of M-banking users (Shankar Amit, 2016). There is a lack of information regarding the motivators of mobile banking adoption (Ho et al., 2020). In this paper, we will try to identify the influential factors of mobile banking adoption.

Despite the beneficial aspects of mobile banking, there are certain risks associated with mobile banking that still need to be addressed. The protection of mobile banking transactions is the greatest danger, as Internet or mobile transactions are vulnerable to the risks of phishing, breaching of accounts, leaks of sensitive information (Mehrad \& Mohammadi, 2017). Moreover, financial illiteracy, lack of financial inclusion, lack of access to the Internet and other means of technology, and the potential danger of online fraud are significant reasons why most customers from developing countries have not yet accepted this service (Kumar et al., 2020).

This paper is focused on Georgia as a developing country. According to (Mushkudiani, 2019), most Georgians still use mobile banking precursors, such as ATM bank branches or telephone banks. This indicates that, along with the introduction of emerging technology, mobile banking's adoption needs to discover the factors that influence its acceptance, which we are looking for in this study in Georgia. This analysis varies from any of the prior research as follows.

To begin with, previous research has been sparse and has mostly concentrated on SMS banking. This research is the first to look into mobile banking solutions for smartphones and tablets.

Furthermore, unlike prior research, this one is aimed at those who use smartphones to access the Internet.

Therefore, the influence of the WOM variable on the mobile banking adoption in Georgia is deemed the paper's primary addition for the very first time in the literature.

The paper is structured accordingly: the next step is to address the literature review and present the hypothesis, then methodology and data analysis; after this, we discuss findings, conclusions, and ideas for future research.

\section{Literature Review Mobile Banking}

Mobile banking is a financial institution or bank service that allows customers to manage their transactions via mobile devices. M-banking can use mobile devices such as smartphones or tablets to access the banking system through wireless protocols. Users can access banking services such as the balance of accounts and statements, e-bill payments, transfers of funds (Sharma \& AlMuharrami, 2018). Mobile banking has received greater prominence in recent times, and the field's growth is speeding up. Due to a rapid increase in smartphone users, banks have transitioned the market environment from physical banking to Internet banking and mobile banking services. Although mobile subscribers have increased massively, mobile banking users' number is below the expected rate (Shankar Amit, 2016). Privacy is a concern for some smartphone users that impact 
their adoption (Min Tun, 2020). Banks have paid attention to financial apps as a source of sustained competitive advantage, developing meaningful customer relationship management (CRM) and facilitating timely and convenient decision-making (Melewar et al., 2017). As mobile banking was introduced, user adoption rates were low, leading to management improvements to convince consumers to turn to this technology. Efforts to improve purchases, along with the growth of mobile devices and foreign economic pressure, were factors that contributed to the rapid acceptance of this technology (Zalloum et al., 2019).

Many banking facilities can be obtained from a mobile device through M-banking. There are some of the advantages of $m$-banking:

- Save money and time: consumers can save money and time with M-banking solution that does not care about banking hours to process transfers and does not need to access a branch on-site (Chong et al., 2019);

- Quick access: Consumers can make a variety of e-transactions, such as money transfers, bill payments, balance checks, credit and debit card transactions, host transactions at any time and anywhere (Chong et al., 2019);

- Improves productivity: banks can boost average efficiency with the high prices of ATMs or bank branches since the costs of $\mathrm{m}$-banking transactions are much smaller than on-site transactions (Nguyen et al., 2020);

- Offers better access: banks should maximize customer participation in real-time transactions, meaning that consumers can have a fair chance of inspecting financial options on any purchase (Chong et al., 2019);

M-banking issues besides rewards, $\mathrm{m}$-banking has dealt with a variety of challenges:

- Protection and privacy: purchases on mobile devices are allowed by service providers, which confirms that unauthorized devices are not connected to transactions and that consumer information is secured (Sharma \& Al-Muharrami, 2018);

- Stability and scalability: m-banking technology manipulates an increasingly increasing client base, so that customers remain in banking at any time and everywhere, and the banks stabilize the 24x7 system (Sharma \& Al-Muharrami, 2018);

- User-friendly: m-banking provisions quick access to e transfers, so banks can create that m-banking applications are user-friendly or easy to use (Nguyen et al., 2020).

Cultural and social variables have been identified as important influencers on mobile banking uptake in studies done in developing regions. (Mehrad \& Mohammadi, 2017). In evaluation of multiple consumer decision-making procedures associated to mobile banking adoption, a number of independent and dependent factors occur. This review identified three major dependent variables (attitude, intention, and usage) as well as eight independent variables (ease of use, perceived usefulness, trust, social influence, perceived risk, perceived behavioural control (or self-efficacy), compatibility with lifestyle and device, and facilitating conditions) (Kim \& Park, 2013).

\section{Technology Acceptance Model (TAM)}

The literature has shown that IT acceptance has been the focus of a great deal of study over the past two decades. One of the leading models is the Technology Acceptance Model (TAM), which examines the factors that affect the implementation of information systems proposed by (Davis, 1989) based on the TPB and TRA and added two new factors: perceived ease of use and perceived usefulness. Researchers have expanded the TAM model by introducing additional structures, integrating them with other hypotheses, analyzing other mediators, or defining the antecedents 
of perceived utility and perceived ease of use. Mobile banking is a modern, state-of-the-art, and complex technology-enabled information system (Singh \& Srivastava, 2020). Davis (1989) proposes the identical properties of belief, behaviour, intention, and behaviour in TAM helps one foresee the usage of emerging technology by consumers. As we mentioned, TAM is an adaptation of the Theory of Reasoned Action (TRA) concerning Information Systems (IS), which states that perceived utility and perceived ease of use decide the individual's behaviour towards its intent to use the implementation to act as a mediator for the actual use of the system (Mohammadi, 2015). However, since the TAM excludes economic and demographic factors, it seems to have restricted the use of conditions and external variables to clarify consumer behaviours and behavioural intentions towards mobile service adoption (Venkatesh et al., 2003). As a result, many mobile banking adoption studies are expanding or complementing the original TAM by adding additional constructs (Ho et al., 2020; Pang, 2021; Purwanto et al., 2020; Van NGUYEN \& NGUYEN, 2020). In reality, TAM allows for the provision to include external variables as determinants of perceived utility and perceived ease of use (Davis, 1989).

TAM has been widely examined and validated and is an extensively accepted model in different sorts of technologies related to user and organization acceptance and adoption such as the World Wide Web (Lederer et al., 2000), Intranet (Horton et al., 2001), E-commerce (Olson \& Boyer, 2003), Internet Banking (Aldas-Manzano et al., 2010), Mobile banking (Van NGUYEN \& NGUYEN, 2020).

\section{Perceived usefulness}

The Construct of perceived usefulness has been taken from the original TAM theory. It has been employed in several studies in various countries (Kumar et al., 2020). An individual often considers the consequences of his/her actions and makes a judgment based on the desirability and perceived usefulness (Min Tun, 2020). The Construct perceived usefulness has been described as the degree to which the device can improve its efficiency as a prospective customer (Davis, 1989). In the Mbanking context, the perceived usefulness is understood as the indicators of saving considerable time and effort $\mathrm{m}$-banking usage, or managing the banking tasks virtually $\mathrm{m}$ - banking usage (Nguyen et al., 2020). We can characterize the Perceived Usefulness of Mobile Banking as the degree to which mobile banking can help meet banking needs. Perceived usefulness has been identified as having a significant positive correlation with both attitude and usage intention. For example, perceived usefulness positively affects the adoption of mobile Internet and mobile services (Changchit et al., 2020). Consumers may use mobile banking services to conduct financial transactions from any place and at any time. (Mohammadi, 2015). In general, clients tend to have a more optimistic outlook about adoption and the use of emerging technologies as they realize the many advantages of mobile banking. Based on mentioned above, we can develop the following hypothesis:

H1: Perceived usefulness positively affects users' attitudes;

H2: Perceived usefulness positively affects the intent of using mobile banking.

\section{Perceived ease of use}

Perceived ease of use is conceptualized as an individual's evaluation of the mental effort involved in the use of modern technologies (Davis, 1989). Several other researchers have found out that perceived ease of use may affect perceived usefulness, since other things being equal, the simpler it is to use, the more valuable it can be (Wang et al., 2010). In internet banking, analysis indicates that perceived ease of use has a strong and essential influence on perceived usefulness (Van 
NGUYEN \& NGUYEN, 2020). Consumers will consider mobile banking services as easy to use if they have user-friendly designs, and this impression will lead to a good perspective towards products. (Tran \& Corner, 2016). Accordingly, the following hypothesis has been developed:

H3: Perceived Ease of use positively affects Perceived usefulness;

H4: Perceived Ease of use positively affects users' attitudes.

\section{Social norm}

PICBE |

A social norm is characterized as an individual's belief that other people who are significant to them agree that they should or should not practice the action in question (Putri et al., 2021). Individuals also respond to normative social pressures to create a flattering appearance in a comparison community (Ajzen \& Fishbein, 1975). On this basis, we cannot neglect the social norm's influence when studying the model of adoption. The literature suggests that social standards significantly affect mobile banking adoption (Aboelmaged \& Gebba, 2013; Breckwoldt et al., 2016).

H5: Social norm positively affects Perceived Ease of use;

H6: Social norm positively affects Perceived usefulness.

\section{Trust}

Trust is at the core of all sorts of partnerships and is a primary determinant of mobile banking's acceptance purpose and various other fintech services. It determines the preferences of consumers from their service providers (Kumar et al., 2020). Trust is an essential component that impacts the behaviour with signify to banking system adoption. In the $\mathrm{M}$-banking context, trust is understood as the $\mathrm{m}$-banking systems will be safe and reliable, keep the customer's best interest in mind, or do not divulge the personal information (Nguyen et al. Kim et al. (2009) have shown that where mobile banking is viewed as being associated with a higher risk than ordinary banking, the primary confidence of the customer in services is articulated as a required consideration for the use of mobile banking. Koenig-Lewis et al. (2010) argued that there is no clear relationship between confidence and the decision to use mobile banking; however, it indirectly impacts the object of use through compatibility and perceived risk variables. Therefore, it seems appropriate to examine this variable and its effect on the user's attitude and function.

H7: Trust positively affects Perceived Ease of using;

H8: Trust positively affects Perceived usefulness.

\section{Attitude and Intention}

The purpose, which is the key dependent variable found in the TAM-based studies, is the probability that the participant will use the technology. The significant antecedent and central mediator of the influence of other factors on the plan to use, according to TAM, is the individual's attitude towards the use of technology (Davis, 1989). Attitude plays a vital role in the application of emerging technologies. In their study of mobile banking acceptance, Shaikh \& Karjaluoto (2015) observed that this mindset had a favourable impact on customers' plans to continue using mobile banking. As a result, behaviours are expected to be a good indicator of their decision to continue using mobile banking.

H9: Attitude towards the use of technology positively affects the intention to use mobile banking; 


\section{Word of Mouth (WOM)}

Communication is a way to convey someone's message to another person to advise or change his or her mentalities, feelings, and behaviour, either legitimately (face to face communication) or in a roundabout way (dissemination through the media) (Thusi \& Maduku, 2020). Communication is seen as an array of communications from official and informal outlets across a good range of newspapers, where organizations will transfer their identities to various audiences (Melewar et al., 2017).

Word of the Mouth (WOM) is one of the most significant information dispersion channels among people. WOM has been known as opinions, exchanges of comments, and ideas among individuals. Individuals do not reflect a marketing source or contact between customers regarding service, commodity, and entity. The sources are perceived to be independent of commercial control. Based on the associated contact with customers regarding service, commodity, and entity, the sources are assumed to have an autonomous commercial impact (Changchit et al., 2020).

Word of mouth is a communication that involves informal communication between customers regarding suppliers or their products/services' characteristics. Word of mouth may be positive or negative to expected customers before they experience a product or service. Customers have various reasons to be involved in word of mouth (Velázquez et al., 2015). Word of mouth is seen as a genuinely sound source of data because the sender is usually free from the association that provides the service. Word of mouth provides a 'two-way exchange of information,' which allows for a more significant effect on individuals at the stage of persuasion. What is more, this is the best method of correspondence (Purwanto et al., 2020).

At the pre-purchase point, individuals seek input from others as a technique for risk mitigation, especially in the sense of services. In reality, customers have more recourse to and trust WOM knowledge when coping with high-risk buying processes (Mehrad \& Mohammadi, 2017). At the post-purchase point, customers engage in WOM with a wide range of goals and motives, primarily to benefit other consumers, avoid potential mistakes, prevent frustration or minimize cognitive dissonance. WOM is a kind of overt, informal activity independent of the organization and makes the information communicated more genuine and reliable. In this regard, the literature recognizes that the impact of WOM on consumer behaviour is more significant than the influence of marketing or advertising (Velázquez et al., 2015).

The opinions and perceptions of consumers about the product's impact purchase intention (Huete-Alcocer, 2017). According to (2017), perceived quality and consumer value obtained through social media have been found to influence consumers' purchase decisions.

H10: Word of Mouth positively affects Perceived Ease of use;

H11: Word of Mouth positively affects Perceived usefulness;

H12: Word of Mouth positively affects social norm;

H13: Word of Mouth positively affects trust;

H14: Word of Mouth positively affects user attitudes;

H15: Word of Mouth positively affects intention of using mobile banking.

\section{Conceptual Framework}

Based on the literature and developed hypotheses, we built the conceptual model (see Figure 1). All the factors mentioned above are used in our model and the relationship between them, which was explained in the hypotheses formulation. 


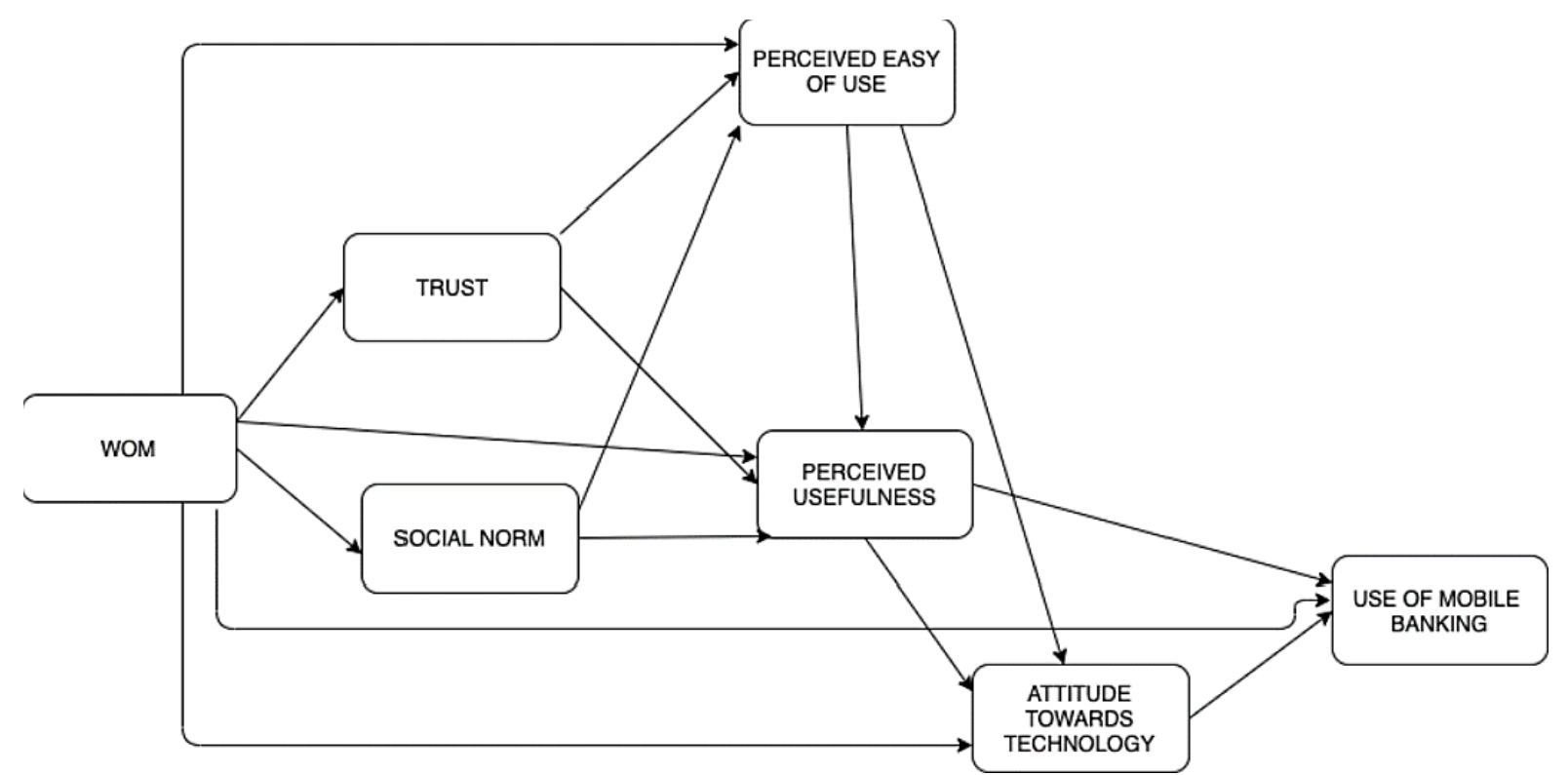

PICBE |

Figure 1. Conceptual model

Source: Authors' own research.

\section{Methodology}

This study was focused on internet users; non-users were not included in the analyzes. The online survey form, which consists of 35 questions, was created and sent through online platforms (Facebook, Instagram, Yahoo, Gmail) to participants. Participation in this study was voluntary. Since the survey was structured and submitted online, participants had to have a mobile phone capable of downloading mobile banking apps and linking to the Internet. The sample for this research was gathered from November 2020 to December 2020. A total of 384 valid samples were taken. For determining the sample size, Cochran's formula was used:

For a total population, the sample size was suggested 384. The total population of Georgia by sex and age group was obtained from Georgia's National Statistics Office (Table 1). We tried to test the sample representativeness, and we realized the sample appears to represent gender and age.

Table 1. The demographic characteristics of the sample.

\begin{tabular}{|l|l|l|}
\hline \multicolumn{1}{|c|}{ Classification } & \multicolumn{1}{|c|}{ Prequency } & \multicolumn{1}{|c|}{ Percentage } \\
\hline Gender & 199 & 51.82 \\
Female & 185 & 48.18 \\
Male & 384 & 100 \\
Total & & \\
& & \\
Age & 84 & 21.88 \\
$20-29$ & 91 & 23.70 \\
$30-39$ & 209 & 54.43 \\
$40+$ & 384 & 100 \\
Total & & \\
\hline
\end{tabular}

Source: National Statistics Office of Georgia, 2020. 


\section{Data Analyses}

Four forms of validity have been determined to estimate the validity of the testing instrument, i.e., content validity, face validity, convergent validity, and discriminative validity. To determine the material's validity, many questionnaires were conducted between marketing and banking experts and professors in the field to determine the instrument's validity. The questionnaire's purpose was to assess the appropriateness and validity of the questions corresponding to each variable. Finally, the substance of the questionnaire was accepted.

The data collection technique has been chosen questionnaire, containing constructs from the conceptual framework, and each Construct will be measured with statements. As the measurement tool of the level of agreement with the statements will be used a Likert scale from one to seven. Initially, the questionnaire was designed in English, afterwards translated into the local language and spread. Before questionnaire distribution, a pilot study was carried out. The pilot study consists of 50 samples to receive feedback regarding the statement's understandability and ambiguity (Connelly, 2008).

Cronbach Alpha was employed to measure the internal consistency, proving the reliability of the questionnaire. The CA reliability was 87, and that confirms the reliability of the questionnaire.

During the next step, the average variance extracted and composite reliability was measured. The purpose of measuring AVE was to show the variance extracted by the indices concerning measurement errors and be more than 0.50 to justify using a construct. The values of $\mathrm{CR}$ and AVE, respectively, more than 0.60 and 0.50 , refer to the appropriate construct reliability and convergent validity (Barclay et al., 1995). The values of AVE and CR are presented in Table 2, indicating the research constructs' acceptable values.

We employed KMO and Bartlett's test to determine if the sample size relationship between variables is suitable and enough for factor analyses. Table 2 shows that the KMO test results for all the factors are more significant than 0.6, and the Bartlett test is less than 0.5 in all the cases. This information gives us the possibility to suggest that the sample is adequate (Hair, 2017). The instrument's discriminant validity was also confirmed by investigating the correlation of different variables' indicators in the AMOS output covariance matrix. In order to estimate discriminant validity, the correlation between the constructs must be less than 0.85 . The correlation coefficient of more than this value indicates that the constructs measure the same concept (Sørensen \& Slater, 2008). Based on the results, there is no similar concept in latent variables. Thus, all constructs have discriminant validity.

Table 2. Main statistics

\begin{tabular}{|c|l|c|c|c|c|c|c|c|c|}
\hline Variable & \multicolumn{1}{|c|}{ Items } & $\mathbf{N}$ & Mean & $\begin{array}{c}\text { Loading } \\
\text { Factor }\end{array}$ & $\begin{array}{c}\text { Cronbach's } \\
\text { Alpha }\end{array}$ & AVE & CR & KMO & Bartlett \\
\hline & $\begin{array}{l}\text { Mobile banking makes } \\
\text { my banking faster }\end{array}$ & 384 & 5.93 & 0.89 & 0.916 & 0.75 & 0.93 & 0.839 & 0.000 \\
\cline { 2 - 9 } & $\begin{array}{l}\text { Mobile banking is } \\
\text { useful for me doing } \\
\text { banking }\end{array}$ & 384 & 5.65 & 0.87 & & & & & \\
\cline { 2 - 10 } $\begin{array}{l}\text { Perceived } \\
\text { Usefulness }\end{array}$ & $\begin{array}{l}\text { Mobile banking } \\
\text { improves the way I do } \\
\text { banking }\end{array}$ & 384 & 5.61 & 0.85 & & & & & \\
\cline { 2 - 12 } & $\begin{array}{l}\text { Mobile banking makes } \\
\text { my banking easier }\end{array}$ & 384 & 5.75 & 0.85 & & & & & \\
\hline
\end{tabular}




\begin{tabular}{|c|c|c|c|c|c|c|c|c|c|}
\hline Variable & Items & $\mathbf{N}$ & Mean & $\begin{array}{l}\text { Loading } \\
\text { Factor }\end{array}$ & $\begin{array}{l}\text { Cronbach's } \\
\text { Alpha }\end{array}$ & AVE & CR & КMO & Bartlett \\
\hline \multirow{4}{*}{$\begin{array}{l}\text { Perceived } \\
\text { Ease of } \\
\text { Use }\end{array}$} & $\begin{array}{l}\text { The interaction with } \\
\text { digital banking is } \\
\text { transparent and clear }\end{array}$ & 384 & 5.46 & 0.79 & 0.902 & 0.71 & 0.91 & 0.819 & 0.000 \\
\hline & $\begin{array}{l}\text { Learning how to use } \\
\text { smartphone financing } \\
\text { will be easy }\end{array}$ & 384 & 5.83 & 0.84 & & & & & \\
\hline & $\begin{array}{l}\text { It is easy for me to use } \\
\text { mobile financial } \\
\text { services }\end{array}$ & 384 & 5.64 & 0.92 & & & & & \\
\hline & $\begin{array}{l}\text { I can quickly become } \\
\text { skilled in using mobile } \\
\text { banking services }\end{array}$ & 384 & 5.37 & 0.83 & & & & & \\
\hline \multirow{4}{*}{$\begin{array}{l}\text { Social } \\
\text { Norms }\end{array}$} & $\begin{array}{l}\text { People who are close to } \\
\text { me recommend me } \\
\text { mobile payment service }\end{array}$ & 384 & 5.08 & 0.85 & 0.891 & 0.69 & 0.89 & 0.787 & 0.000 \\
\hline & $\begin{array}{l}\text { People who are close to } \\
\text { me use mobile payment } \\
\text { services }\end{array}$ & 384 & 5.14 & 0.93 & & & & & \\
\hline & $\begin{array}{l}\text { People who are close to } \\
\text { me think using mobile } \\
\text { payment is a good idea }\end{array}$ & 384 & 5.23 & 0.88 & & & & & \\
\hline & $\begin{array}{l}\text { More people around me } \\
\text { use mobile banking } \\
\text { services }\end{array}$ & 384 & 4.53 & 0.65 & & & & & \\
\hline \multirow{4}{*}{ Trust } & $\begin{array}{l}\text { Mobile banking service } \\
\text { is reliable for me }\end{array}$ & 384 & 4.99 & 0.74 & 0.847 & 0.59 & 0.86 & 0.801 & 0.000 \\
\hline & $\begin{array}{l}\text { Mobile banking service } \\
\text { helps costumers }\end{array}$ & 384 & 5.68 & 0.75 & & & & & \\
\hline & $\begin{array}{l}\text { Banks are fulfilling } \\
\text { their duties regarding } \\
\text { mobile banking }\end{array}$ & 384 & 4.79 & 0.75 & & & & & \\
\hline & $\begin{array}{l}\text { I trust my bank } \\
\text { regarding mobile } \\
\text { banking }\end{array}$ & 384 & 5.15 & 0.87 & & & & & \\
\hline \multirow{3}{*}{ WOM } & $\begin{array}{l}\text { I talk about advantages } \\
\text { of mobile banking to } \\
\text { people I know }\end{array}$ & 384 & 4.97 & 0.74 & 0.878 & 0.71 & 0.88 & 0.715 & 0.000 \\
\hline & $\begin{array}{l}\text { I usually talk positively } \\
\text { regarding mobile } \\
\text { banking }\end{array}$ & 384 & 5.06 & 0.86 & & & & & \\
\hline & $\begin{array}{l}\text { I usually recommend } \\
\text { mobile banking to } \\
\text { people }\end{array}$ & 384 & 5.26 & 0.93 & & & & & \\
\hline \multirow{4}{*}{ Attitude } & $\begin{array}{l}\text { Mobile banking fits my } \\
\text { lifestyle }\end{array}$ & 384 & 5.26 & 0.89 & 0.904 & 0.71 & 0.91 & 0.805 & 0.000 \\
\hline & $\begin{array}{l}\text { Banking services fit the } \\
\text { most banking activities }\end{array}$ & 384 & 5.15 & 0.81 & & & & & \\
\hline & $\begin{array}{l}\text { Mobile payment is } \\
\text { good idea }\end{array}$ & 384 & 5.56 & 0.84 & & & & & \\
\hline & $\begin{array}{l}\text { Mobile payments are } \\
\text { beneficial }\end{array}$ & 384 & 5.55 & 0.85 & & & & & \\
\hline
\end{tabular}

PICBE | 385 


\begin{tabular}{|c|c|c|c|c|c|c|c|c|c|}
\hline Variable & Items & $\mathbf{N}$ & Mean & $\begin{array}{c}\text { Loading } \\
\text { Factor }\end{array}$ & $\begin{array}{c}\text { Cronbach's } \\
\text { Alpha }\end{array}$ & AVE & CR & KMO & Bartlett \\
\hline \multirow{4}{*}{ Intention } & $\begin{array}{l}\text { I will use mobile } \\
\text { banking }\end{array}$ & 384 & 5.55 & 0.89 & 0.894 & 0.69 & 0.91 & 0.821 & 0.000 \\
\hline & $\begin{array}{l}\text { I would like to have } \\
\text { more info regarding } \\
\text { mobile banking }\end{array}$ & 384 & 5.69 & 0.67 & & & & & \\
\hline & $\begin{array}{l}\text { I will use mobile } \\
\text { banking for my } \\
\text { payments }\end{array}$ & 384 & 5.55 & 0.89 & & & & & \\
\hline & $\begin{array}{l}\text { I manage my bank } \\
\text { account through mobile } \\
\text { banking }\end{array}$ & 384 & 5.43 & 0.86 & & & & & \\
\hline
\end{tabular}

PICBE |

\section{Results}

Structural Equation Modeling (SEM) was used to analyze the data in this paper. We also used path analyses to show the relationship between dependent and independent variables. To prove that this model is a good model for the analyses, we used $\chi^{2} / \mathrm{df}$ statistics and other measures. According to AMOS results (table 3), we can agree that this model is good. Adjusted Goodness-of-Fit Index (AGFI=.808) verified that our model presents an incremental adjustment except for the last value, which is slightly below the reference value of .90 .

Table 3. Measures of goodness of fit

\begin{tabular}{|c|c|c|c|c|c|c|c|}
\hline Statistics & $\chi^{2} / \mathbf{d f}$ & RMSE & PMR & CFI & TLI & AGFI & P-Value \\
\hline $\begin{array}{c}\text { Suitable } \\
\text { values }\end{array}$ & $3>$ & $0.09>$ & $0.11>$ & $0.1<$ & $0.1<$ & $0.9<$ & $0.06>$ \\
\hline $\begin{array}{c}\text { Values } \\
\text { obtained }\end{array}$ & 3.197 & 0.077 & 0.079 & 0.927 & 0.918 & 0.808 & 0.000 \\
\hline
\end{tabular}

Source: Authors own research.

The next step is to discuss the relationship between constructs. The first one is the positive relationship between perceived usefulness and attitude toward the use of mobile banking. We calculated the Beta coefficient of 0.38 and $\mathrm{t}$-value $=4.18$. the results confirm the positive relationship between the constructs mentioned above. This case was studied in previous researches, as we argued in the literature review section before. The second path shows that perceived usefulness also increases mobile banking's intention, and the second hypothesis is accepted too $(\beta=0.69, \mathrm{t}$-value $=4.56)$. The third path also shows the positive relationship between ease of use and usefulness $(\beta=0.74$, t-value $=11.34)$. According to table 4 results, we accept all the hypotheses.

Table 4. Standard coefficients and significance values for 15 hypotheses

\begin{tabular}{|c|l|c|c|c|c|}
\hline Hypothesis & \multicolumn{1}{|c|}{ Path } & $\begin{array}{c}\text { Path } \\
\text { Coefficient }\end{array}$ & t-value & Sig. & result \\
\hline H1 & Usefulness...Attitude & 0.38 & 4.18 & 0.000 & Accepted \\
\hline H2 & Usefulness...Intention & 0.69 & 4.55 & 0.000 & Accepted \\
\hline H3 & Ease of Use...Usefulness & 0.74 & 11.34 & 0.000 & Accepted \\
\hline H4 & Ease of Use...Attitude & 0.63 & 10.29 & 0.000 & Accepted \\
\hline H5 & Social Norms...Ease of Use & 0.32 & 3.8 & 0.000 & Accepted \\
\hline H6 & Social Norms...Usefulness & 0.37 & 4.55 & 0.000 & Accepted \\
\hline H7 & Trust...Ease of Use & 0.23 & 2.98 & 0.003 & Accepted \\
\hline
\end{tabular}




\begin{tabular}{|c|l|c|c|c|c|}
\hline Hypothesis & \multicolumn{1}{|c|}{ Path } & $\begin{array}{c}\text { Path } \\
\text { Coefficient }\end{array}$ & t-value & Sig. & result \\
\hline H8 & Trust...Usefulness & 0.48 & 2.99 & 0.003 & Accepted \\
\hline H9 & Attitude...Intention & 0.33 & 2.11 & 0.036 & Accepted \\
\hline H10 & WOM...Ease of use & 0.58 & 3.36 & 0.000 & Accepted \\
\hline H11 & WOM...usefulness & 0.56 & 2.22 & 0.027 & Accepted \\
\hline H12 & WOM...Social Norms & 0.61 & 12.94 & 0.000 & Accepted \\
\hline H13 & WOM...Trust & 0.69 & 12.19 & 0.000 & Accepted \\
\hline H14 & WOM...Attitude & 0.86 & 14.94 & 0.000 & Accepted \\
\hline H15 & WOM...Intention & 0.79 & 3.03 & 0.002 & Accepted \\
\hline
\end{tabular}

Source: Authors own research.

\section{Conclusion and Discussion}

The empirical analysis demonstrated several significant findings. Perceived ease of use and perceived usefulness significantly impacted consumers' attitudes towards their intention to continue using mobile banking. Perceived ease of use also affected perceived usefulness, which played a mediating role between attitude and intention. The findings revealed that views regarding mobile banking are significantly influenced by perceived benefits. This conclusion syncs with several previous studies (Tran \& Corner, 2016), (Shaikh \& Karjaluoto, 2015), (Min Tun, 2020). When customers feel that service fees and time can be reduced, banking is becoming easier and faster, some additional services and offers can be suggested, and they tend to use mobile banking.

Social norms and trust have direct and positive effects on perceived usefulness. These two constructs also impact attitude and intended use. According to the results, social norms also influence the ease of use. Based on this, increasing customer banking knowledge may cause the trend to use mobile banking more. It is also recommended that bank employers invite more of their relatives and friends to use mobile banking.

Finally, the results show that WOM positively affects attitude, Intention, Trust, social norms, Ease of use, and perceived usefulness. This can be considered the main contribution of this study and a step forward in the researches carried out in this area (Mushkudiani, 2019). According to Georgia's culture and technological boom, bank managers share some information indirectly. It is also recommended that bank employers invite more of their relatives and friends to use mobile banking, or banks can benefit consumers who may recommend the Bank app to other clients. As research shows, as more people use and recommend m-banking, potential users will perceive it as more comfortable to use and more useful. Further, has perceived usefulness has a positive impact on mobile banking, which will increase the number of users.

Other communication strategies could be used, such as using social influencers to show how useful, trustworthy, and easy to use is the app, leading to increased m-banking use.

This study's uniqueness is that none of the researchers reviewed WOM as a new parameter for adopting mobile banking in Georgia.

In conclusion, this study indicates that if consumers learn mobile banking's features and advantages, trust the system, realize that operating with this modern technology is helpful and convenient, and hear a positive opinion about mobile banking services, mobile banking services will be used. As a result, banks and financial institutions should be mindful that if consumers have a good outlook towards mobile banking, they will try to use it. Making people aware of technology's benefits through social media, growing financial facilities through mobile apps, and enhancing Internet connectivity efficiency can help merge the banking system with International Digital Banking and increase its accessibility. 


\section{Limitations and recommendations for further research}

This study's most significant limitation is that it only studied internet users, and non-internet users were excluded from the study. Also, survey participants were just Georgian individuals, so it is recommended to study other developing countries' individuals, and a convenience sample was used.

We did not consider demographic factors. Future research will be essential to study adoption based on age, gender, income, or education. Further, it may be interesting to compare the results obtained in Georgia to other countries and research the impact of eWOM on m-banking use.

This research focused on some consequences of eWOM; in the future other consequents could be researched.

\section{Acknowledgement}

The authors would like to thank the Internal Grant Agency of FaME for providing financial support to carry out this research. Funding was extended through: TBU in Zlín No. IGA/FaME/2020/002; Project title: The impact of digital transformation on customer behaviour and firm's sustainable development.

\section{References}

Aboelmaged, M., \& Gebba, T. R. (2013). Mobile Banking Adoption: An Examination of Technology Acceptance Model and Theory of Planned Behavior. International Journal of Business Research and Development, 2(1), https://doi.org/10.24102/ijbrd.v2i1.263.

Ajzen, I., \& Fishbein, M. (1975). Belief, attitude, intention and behaviour: An introduction to theory and research. Reading, MA: Addison-Wesley, https://www.researchgate.net/ publication/233897090_Belief_attitude_intention_and_behaviour_An_introduction_to_th eory_and_research.

Al-Adwan, A.S., \& Sammour, G. (2020). What Makes Consumers Purchase Mobile Apps: Evidence from Jordan. Journal of Theoretical and Applied Electronic Commerce Research, 16(3), 562-583, https://doi.org/10.3390/jtaer16030034.

Aldas-Manzano, J., Ruiz-Mafe, C., Sanz-Blas, S., \& Lassala-Navarré, C. (2010). Internet banking loyalty: evaluating the role of trust, satisfaction, perceived risk and frequency of use. Http://Dx.Doi.Org/10.1080/02642060903433997, https://doi.org/10.1080/0264206090343 3997.

Barclay, D., Thompson, R., \& Higgins, C. (1995). The partial least squares (PLS) approach to causal modelling: personal computer adoption and use as an illustration. Technology Studies. https://www.scopus.com/record/display.uri?eid=2-s2.0-84964343482\&origin=in ward.

Breckwoldt, M., Hellstrand, A., \& Sayed, Z. (2016). Title: Consumer acceptance of mobile banking in Germany.

Changchit, C., Klaus, T., Lonkani, R., \& Sampet, J. (2020). A Cultural Comparative Study of Mobile Banking Adoption Factors. Journal of Computer Information Systems, 60(5), 484-494, https://doi.org/10.1080/08874417.2018.1541724.

Chong, A., Chan, F., \& Ooi, K. (2019). Predicting consumer decisions to adopt mobile commerce: Cross country empirical examination between China and Malaysia. Business, Computer Science. https://www.bibsonomy.org/bibtex/57bb493ecbd893b24e09ce09c9179ac5. 
Connelly, L. M. (2008). Pilot studies. Medsurg Nursing: Official Journal of the Academy of Medical-Surgical Nurses, 17(6), 411-412.

Dass, R., \& Pal, S. (2011). Exploring the factors affecting the adoption of mobile financial services among the rural under-banked. Association for Information Systems.

Davis, F. D. (1989). Perceived usefulness, perceived ease of use, and user acceptance of information technology. MIS Quarterly: Management Information Systems, 13(3), 319-339, https://doi.org/10.2307/249008.

PICBE |

Hair, J. F. (2017). A primer on partial least squares structural equations modeling (PLS-SEM). SAGE.

Ho, J. C., Wu, C.-G., Lee, C.-S., \& Pham, T.-T. T. (2020). Factors affecting the behavioral intention to adopt mobile banking: An international comparison. Technology in Society, 63, 101360, https://doi.org/10.1016/j.techsoc.2020.101360.

Horton, R. P., Buck, T., Waterson, P. E., \& Clegg, C. W. (2001). Explaining intranet use with the technology acceptance model. Journal of Information Technology, 16(4), 237-248. https://doi.org/10.1080/02683960110102407.

Huete-Alcocer, N. (2017). A literature review of word of mouth and electronic word of mouth: Implications for consumer behavior. Frontiers in Physiology, 8(JUL), https://doi.org/ 10.3389/fpsyg.2017.01256.

Kim, S., \& Park, H. (2013). Effects of various characteristics of social commerce (s-commerce) on consumers' trust and trust performance. International Journal of Information Management, 33(2), 318-332. https://doi.org/10.1016/j.ijinfomgt.2012.11.006.

Kudeshia, C., \& Kumar, A. (2017). Social eWOM: does it affect the brand attitude and purchase intention of brands? Management Research Review, 40(3), 310-330, https://doi.org/ 10.1108/MRR-07-2015-0161.

Kumar, A., Dhingra, S., Batra, V., \& Purohit, H. (2020). A Framework of Mobile Banking Adoption in India. Journal of Open Innovation: Technology, Market, and Complexity, 6(2). https://doi.org/10.3390/JOITMC6020040.

Lederer, A. L., Maupin, D. J., Sena, M. P., \& Zhuang, Y. (2000). Technology acceptance model and the World Wide Web. Decision Support Systems, 29(3), 269-282, https://doi.org/ 10.1016/S0167-9236(00)00076-2.

Matute, J., Polo-Redondo, Y., \& Utrillas, A. (2016). The influence of EWOM characteristics on online repurchase intention: Mediating roles of trust and perceived usefulness. Online Information Review, 40(7), 1090-1110, https://doi.org/10.1108/OIR-11-2015-0373.

Mehrad, D., \& Mohammadi, S. (2017). Word of Mouth impact on the adoption of mobile banking in Iran. Telematics and Informatics, 34(7), 1351-1363, https://doi.org/10.1016/j.tele. 2016.08.009.

Melewar, T.C., Foroudi, P., Gupta, S., Kitchen, P.J., \& Foroudi, M.M. (2017). Integrating identity, strategy and communications for trust, loyalty and commitment, European Journal of Marketing, 51(3), 572-604, https://doi.org/10.1108/EJM-08-2015-0616.

Min Tun, P. (2020). Factors Influencing Intention to Reuse Mobile Banking Services for the Private Banking Sector in Myanmar Mobile Financial Services in Myanmar View project Factors Influencing Intention to Reuse Mobile Banking Services for the Private Banking Sector in Mya. Asean Journal of Management \& Innovation, https://doi.org/10.14456/ajmi.2020.5.

Mohammadi, H. (2015). A study of mobile banking usage in Iran. International Journal of Bank Marketing, 33(6), 733-759, https://doi.org/10.1108/IJBM-08-2014-0114. 
Mushkudiani, N. (2019). Development of Electronic Payments in Georgia. Economics and Culture, 15(2), 64-74, https://doi.org/10.2478/jec-2018-0021.

National Statistics Office of Georgia. (2020). Population and Demography - National Statistics Office of Georgia, https://www.geostat.ge/en/single-categories/114/population.

Nguyen, T. D., Nguyen, T. Q. L., Nguyen, T. V., \& Tran, T. D. (2020). Intention to Use MBanking: The Role of E-WOM. Advances in Intelligent Systems and Computing, 940, 215-229, https://doi.org/10.1007/978-3-030-16657-1_20.

Olson, J. R., \& Boyer, K. K. (2003). Factors influencing the utilization of Internet purchasing in small organizations, Journal of Operations Management, 21(2), 225-245, https://doi.org/ 10.1016/S0272-6963(02)00089-X.

Pang, H. (2021). Identifying associations between mobile social media users' perceived values, attitude, satisfaction, and eWOM engagement: The moderating role of affective factors. Telematics and Informatics, 59, 101561, https://doi.org/10.1016/j.tele.2020.101561.

Purwanto, E., Deviny, J., \& Mutahar, A. M. (2020). The Mediating Role of Trust in the Relationship between Corporate Image, Security, Word of Mouth and Loyalty in MBanking Using among the Millennial Generation in Indonesia. Management and Marketing, 15(2), 255-274. https://doi.org/10.2478/mmcks-2020-0016.

Putri, G. A., Wijayanti, A. W., \& Ariani, K. R. (2021). The Application of Technology Acceptance Model to Assess the Role of Complexity Toward Customer Acceptance on Mobile Banking. Lecture Notes in Networks and Systems, 149, 259-265, https://doi.org/10.1007/ 978-981-15-7990-5_25.

Shaikh, A. A., \& Karjaluoto, H. (2015). Mobile banking adoption: A literature review. In Telematics and Informatics, 32(1), 129-142, Elsevier Ltd. https://doi.org/10.1016/j.tele. 2014.05.003.

Shankar Amit. (2016). Factors Affecting Mobile Banking Adoption Behavior in India. Journal of Internet Banking and Commerce. https://www.researchgate.net/publication/301678538_ Factors_Affecting_Mobile_Banking_Adoption_Behavior_in_India.

Sharma, S. K., \& Al-Muharrami, S. (2018). Mobile Banking Adoption: Key Challenges and Opportunities and Implications for a Developing Country. In Emerging Markets from a Multidisciplinary Perspective, 75-86, https://doi.org/10.1007/978-3-319-75013-2_7.

Singh, S., \& Srivastava, R. K. (2020). Understanding the intention to use mobile banking by existing online banking customers: an empirical study, Journal of Financial Services Marketing, 25(3-4), 86-96, https://doi.org/10.1057/s41264-020-00074-w.

Sørensen, H. E., \& Slater, S. F. (2008). Development and empirical validation of symmetric component measures of multidimensional constructs: customer and competitor orientation. Psychological Reports, 103(1), 199-213, https://doi.org/10.2466/PR0.103.1.199-213.

Thusi, P., \& Maduku, D. K. (2020). South African millennials' acceptance and use of retail mobile banking apps: An integrated perspective. Computers in Human Behavior, 111, https://doi.org/10.1016/j.chb.2020.106405.

Tran, H. T. T., \& Corner, J. (2016). The impact of communication channels on mobile banking adoption. International Journal of Bank Marketing, 34(1), 78-109, https://doi.org/ 10.1108/IJBM-06-2014-0073.

Van Nguyen, A., \& Nguyen, T. P. T. (2020). An Integrated Model of CSR Perception and TAM on Intention to Adopt Mobile Banking. Journal of Asian Finance, Economics and Business, 7(12), 1073-1087, https://doi.org/10.13106/JAFEB.2020.VOL7.NO12.1073. 
Velázquez, B. M., Blasco, M. F., \& Gil Saura, I. (2015). La adopción de la TIC en hoteles y el boca-oreja electrónico. Academia Revista Latinoamericana de Administracion, 28(2), 227-250, https://doi.org/10.1108/ARLA-10-2013-0164.

Venkatesh, V., Morris, M. G., Davis, G. B., \& Davis, F. D. (2003). User Acceptance of Information Technology: Toward a Unified View. MIS Quarterly, 27(3), 425, https://doi.org/10.2307/ 30036540.

Wang, P. W., Su, Y. J., Shih, M. L., \& Luo, S. D. (2010). Analysis of online Word-of-mouth in PICBE | online forums regarding notebook computers, Journal of Convergence Information Technology, 5(5), https://doi.org/10.4156/jcit.vol5.issue5.13.

Yu, P. L., Balaji, M. S., \& Khong, K. W. (2015). Building trust in internet banking: A trustworthiness perspective. In Industrial Management and Data Systems, 115(2), 235-252, Emerald Group Publishing Ltd, https://doi.org/10.1108/IMDS-09-2014-0262.

Zalloum, L., Alghadeer, H., \& Nusairat, N. (2019). The Effect of Using Mobile Banking Services Applications on Electronic Word of Mouth: The Mediating Role of Perceived Trust. International Business Research, 12(9), https://doi.org/10.5539/ibr.v12n9p62. 